\title{
Sistematización de cuestionarios para egresados universitarios y empleadores de la Región Zumpango, Estado de México
}

Systematization of questionnaires for university graduates and employers in the Zumpango Region, State of Mexico Sistematização de questionários para graduados universitários e empregadores na Zumpango, Estado do México região

DOI: http://dx.doi.org/10.23913/reci.v6i11.64

Elvira Ivone González Jaimes

Centro Universitario Zumpango, Universidad Autónoma del Estado de México, México ivonegj@hotmail.com

Asdrúbal López Chau

Centro Universitario Zumpango, Universidad Autónoma del Estado de México, México alchau@uaemex.mx

Rafael Rojas Hernández

Centro Universitario Zumpango, Universidad Autónoma del Estado de México, México rrojashe@uaemex.mx

\section{Resumen}

La presente investigación propone la implementación del Sistema Operativo LimeSurvey en la Encuesta Electrónica ALFA TUNING para medir competencias académicas de egresados y su empleabilidad en región de Zumpango.

Material: Encuesta Electrónica ALFA TUNING.

Objetivo: ayudar a obtener información sobre la empleabilidad de los egresados, indicadores requeridos por los organismos certificadores para medir la calidad educativa. 
Metodología: diseño no experimental, uso de muestras aleatorias, con cortes trasversales y estadística descriptiva. Dividido en cuatro fases: Fase 0, validez de contenidos del Cuestionario ALFA TUNING con coordinadores académicos; Fase 1, prueba piloto de la Encuesta Electrónica ALFA TUNING; fase 2, aplicación de la encuesta a egresados; fase 3, aplicación de encuentra a empleadores.

Resultados: La comparación de seis investigaciones podemos decir que la en encuesta utilizada para el Programa de Movilidad Universitaria Internacional (PMUI) y el sistema LimeSurvey; ambas presenta tiempos estimados menor a dos horas, pero el tiempo utilizado en el sistema LimeSurvey es seis veces menor al sistema utilizado en la plataforma PMUI. Referente al costo en uso, la Encuesta Electrónica ALFA TUNING a través del sistema operativo LimeSurvey presenta un costo menor que todos los sistemas operativos.

Palabras clave: calidad en la educación, egresados, empleo, mercado de trabajo.

\section{Abstract}

This research proposes the implementation of the LimeSurvey operating system in the ALFA TUNING Electronic Survey to measure the academic competencies of graduates and their employability in the Zumpango region.

Title: "Systematization of the questionnaires for graduates of the UA CU Zempango and employers of the Zumpango Region, State of Mexico"

Summary

This research proposes the implementation of the LimeSurvey operating system in the ALFA TUNING Electronic Survey to measure the academic competencies of graduates and their employability in the Zumpango region.

Material: Electronic Survey ALFA TUNING, objective to help obtain information on the employability of graduates. Indicators required by accrediting agencies to measure educational quality. 
Methodology Non-experimental design, use of random samples, with cross-sections and descriptive statistics. Divided into four phases: Phase 0 content validity of the ALFA TUNING questionnaire with academic coordinators. Phase 1 Pilot Test of the ALFA TUNING Electronic Survey. Phase 2 application of the survey to graduates and phase 3 application of employers.

Results: The comparison of six investigations we can say that in the survey used for the International University Mobility Program (PMUI) and the LimeSurvey system; Both have estimated times less than two hours, but the time used in the LimeSurvey system is six times smaller than the system used in the PMUI platform. Regarding the cost, the ALFA TUNING Electronic Survey through the LimeSurvey operating system presents a lower cost than all the operating systems.

Key words: Quality in education, graduates, employment, labor market.

\section{Resumo}

Esta pesquisa propõe a implementação do Sistema Operacional no TUNING Pesquisa LimeSurvey Eletrônica ALFA para medir habilidades acadêmicas e empregabilidade dos diplomados na região Zumpango.

Material: Pesquisa Eletrônica ALFA TUNING.

Objectivo: Para ajudar a obter informações sobre a empregabilidade dos diplomados, indicadores exigidos pelos organismos de certificação para medir a qualidade do ensino.

Metodologia: desenho não experimental, usando amostras aleatórias com cortes transversais e estatísticas descritivas. Dividido em quatro fases: Fase 0, validade de conteúdo dos coordenadores acadêmicos questionário ALFA TUNING; Fase de teste 1 Pilot Pesquisa Eletrônica ALFA TUNING; Fase 2 de implementação dos graduados da pesquisa; Fase 3, os empregadores encontrar aplicação. 
Resultados: Comparação de seis investigações pode-se dizer que a pesquisa utilizada no Programa de Mobilidade Acadêmica Internacional (PMUI) e sistema de LimeSurvey; ambos com menos de duas horas de tempo de estimativa, mas o tempo gasto no sistema LimeSurvey é seis vezes menor do que o sistema usado na plataforma PMUI. Sobre o custo em uso, a pesquisa eletrônica ALFA TUNING através do sistema operacional tem um LimeSurvey menor custo de todos os sistemas operacionais.

Palavras-chave: educação de qualidade, graduados, de emprego, do mercado de trabalho.

Fecha Recepción: Mayo $2016 \quad$ Fecha Aceptación: Noviembre 2016

\section{Introduction}

The Follow-up of Graduates is a method of evaluation and certification of the quality of the Institutions of Higher Education to measure the capacity that the graduates have in terms of obtaining and conserving the employment. Considering it as an index of quality, because it represents the ultimate goal that is intended, which implies fully training students to enter the labor market effectively.

In practice the evaluations of graduates and employers provide a diagnosis, which will allow us to detect essential elements of orientation and educational support for the academic development of the student, leading the student to a quality education (Esteve, 2009).

The certifications or evaluations of Higher Education Institutions (IES) in Mexico, have as main objective to achieve the recognition of quality and academic competitiveness. Among the agencies that carry out these evaluations are the Interinstitutional Committees for the Evaluation of Higher Education (CIEES) directed by the National Association of Universities and Institutions of Higher Education (ANUIES) and the Council for Accreditation of Higher Education A.C. (COPAES), which is the only instance authorized by the Federal Government through the Ministry of Public Education (SEP) to accredit higher education programs in Mexico (Del Castillo, 2010). 
Organizations adhere to Mexican educational evaluation criteria in order to contribute to raising the quality of higher-level academic programs effectively and impartially (Del Castillo, 2010).

Principles governing COPAES:

- Fairness and impartiality.

- Congruence and reliability.

- Control and quality assurance.

- Responsibility and seriousness.

- Transparency and accountability.

Within the academic competitions, the terminal efficiency, number of graduates and their status as interns or graduates are measured, who obtain employment in the first six months after their graduation, among others related to graduates and their employers. Academic competitiveness is intimately related to academic ability and directly accounts for the quality of the services offered by the institution to the community. 
Table 1. List of certifying bodies that evaluate the University Center UAEM Zumpango.

\begin{tabular}{|c|c|}
\hline Carreras & Organismo Certificador \\
\hline \multicolumn{2}{|l|}{ Licenciaturas } \\
\hline $\begin{array}{l}\text { Ciencias Políticas y } \\
\text { Administración Pública }\end{array}$ & $\begin{array}{l}\text { Asociación para la Acreditación y Certificación de } \\
\text { Ciencias Sociales, A. C. (ACCECISO) }\end{array}$ \\
\hline Sociología & $\begin{array}{l}\text { Asociación para la Acreditación y Certificación de } \\
\text { Ciencias Sociales, A. C. (ACCECISO) }\end{array}$ \\
\hline Derecho & $\begin{array}{l}\text { Consejo Nacional para la Acreditación de la Educación } \\
\text { Superior en Derecho, A.C. (CONFEDE) }\end{array}$ \\
\hline Psicología & $\begin{array}{l}\text { Consejo Nacional para la Enseñanza e Investigación en } \\
\text { Psicología, A.C. (CNEIP) }\end{array}$ \\
\hline Turismo & $\begin{array}{l}\text { Licenciatura en Turismo Consejo Nacional para la Calidad } \\
\text { de la Educación Turística, A.C. (CONAET) }\end{array}$ \\
\hline Contaduría & $\begin{array}{l}\text { Consejo de Acreditación de la Enseñanza en la Contaduría } \\
\text { y Administración, A.C (CACECA) }\end{array}$ \\
\hline Administración & $\begin{array}{l}\text { Consejo de Acreditación de la Enseñanza en la Contaduría } \\
\text { y Administración, A.C (CACECA) }\end{array}$ \\
\hline $\begin{array}{l}\text { Enfermería y su } \\
\text { maestría }\end{array}$ & $\begin{array}{l}\text { Consejo Mexicano de Acreditación y Certificación de la } \\
\text { Enfermería, A. C. (COMACE) }\end{array}$ \\
\hline Diseño Industrial & $\begin{array}{l}\text { Consejo Mexicano para la Acreditación de Programas de } \\
\text { Diseño, A.C. (COMAPROD) }\end{array}$ \\
\hline \multicolumn{2}{|l|}{ Ingenierías } \\
\hline Computación & $\begin{array}{l}\text { Consejo Nacional de Acreditación en Informática y } \\
\text { Computación (CONAIC) }\end{array}$ \\
\hline $\begin{array}{l}\text { Agrónomo en } \\
\text { Producción }\end{array}$ & $\begin{array}{l}\text { Comité Mexicano de Acreditación de la Educación } \\
\text { Agronómica, A.C. (COMEAA) }\end{array}$ \\
\hline
\end{tabular}

The systematization of the ALFA TUNING questionnaires for graduates and specific employers for each of the races will facilitate the registration, storage and obtaining of data required to obtain indexes of the development and impact of the races in their habitat.

It should not be forgotten that the questionnaires are a complement to the System of Followup of Graduates (SISE). The set of both systems will give us, general information (SISE) and specific information (ALPHA TUNING). What results as an innovative, specific and necessary product, applied in an agile, intuitive, truthful and reliable way for the users; To 
support the periodic certification that is carried out within the University Center UAEM Zumpango in its eleven careers and a university graduate.

This product will help to carry out the analyzes of Follow-up of Graduates and Employers to have the register of the strengthening of the academic competences, which gives us the panorama of the integration to the Labor Market of the graduates of the University Center UAEM Zumpango, to support the programs Education and with it a comprehensive education (Hogan, 2004).

Measuring academic competitiveness on a continuous basis is a must, because educational institutions must be aware of the economic crisis and the changing roles in the labor market, governed by supply and demand in the areas of production, which has influenced In high growth of the unemployment levels at world-wide level, causing that the university graduates do not find employment. Faced with this socio-economic conflict, higher education institutions were asking themselves. What factors should be improved in order for their graduates to meet the demands of the labor market and therefore the human resources instructed within the institution of higher education have acceptable indexes of insertion into working life (Valenti and Varela, 2004).

Educational quality indices are parameters frequently measured by various institutions to increase educational competitiveness. One of the indicators to measure educational quality is the periodic evaluation of the performance of its graduates in the labor market, which allows to observe the impact that this institution has in the economically active society. The analysis of the trajectories of the graduates allows to determine the mobility or the stagnation of the graduates in four aspects: personal, academic, occupational and professional.

In order to undertake this study, we performed a review of the last indices requested by the accrediting organizations regarding the categories of graduates and employers, where we found both personal and contextual factors that affect the income and the permanence of the graduates, such as : "High levels of stress, perception of poor social support, as well as deficient communicative skills and assertiveness" (Román, 2007: 6), on the other hand we have "satisfaction with the teaching received", this satisfaction is closely related to The 
acquisition of competences highly applicable in the labor market (Fernández, Fernández, Álvarez and Martínez, 2007: 212-213), we continue with teaching-learning processes adjusted to the learning programs to favor the development of specific and transversal competences " That conform to the reality in which they live so that the students are in motivated and improve their performance, knowing that his knowledge will be applicable to future employment "(Cano, 2008: 14-15).

\section{Background of ALFA TUNING Questionnaires}

The TUNING project was created by European universities and presented within the conference TUNING Educational Structures in 2003. Its aim is to measure and compare learning outcomes expressed in terms of generic and specific skills in each area as credits recorded in professional development. Issued questionnaires have high levels of reliability and validity with a universal language to measure various disciplinary areas regardless of the location where you study. Skills development measures on: 1) The new educational paradigm, where educational efforts focus on individual learning, where learning to learn operationally is considered the cornerstone; 2) The need for quality and increased access to employment and responsible citizenship. Evaluating the solution of crucial problems in the labor world, typical of a society in permanent transformation; 3) The creation of Higher Education, projected at similar institutions in teaching quality and universal application as required by globalization (González y Wagenaar, 2006; González y Suarez, 2016).

The TUNING Questionnaire for Latin America Academic Training (ALFA, TUNING) has the same bases as the TUNING Questionnaire, where it is observed that it goes from being a project to being a universal evaluation methodology. It was brought to Latin America to meet the needs for compatibility and comparability of higher education requested in the world labor market. Its goal is to identify and share information that is indispensable for improving the collaboration between Latin American Higher Education Institutions for the development of quality, effectiveness and educational transparency, in an articulated way. Its starting point is the academic competences required to enter and sustain the global labor market (Beneitone, Esquetini, González, Maletá, Siufi, and Wagenaar, 2007). 
Validated by eighteen Latin American countries and represented by 230 higher education academics, they worked hard to achieve educational consensus, forming 16 research networks and a responsible network of university policies to endorse the homogenization and revalidation of studies.

The systematic application of this questionnaire will facilitate us to provide inputs for the evaluation and planning of educational policies (SEP, ANUIES, IES) and to accrediting institutions of careers. As stated in Article 4 of the Regulations of Professional Studies, p. 193, UAE: "The primary purpose of professional studies is the training of students, by developing their faculties, skills, attitudes and values, to carry out high-quality professional activities and to evolve in the labor field, as well as to perform in The investigation, creation and recreation of knowledge "(UAEM, 2008).

The methodological process to validate and standardize the electronic questionnaires for graduates and employers (see section on Scientific Methodology) and specifications of use and evaluation (see technical file).

\section{Methodology}

\section{General objective}

To systematize the ALFA TUNING Questionnaire with the LimeSurvey operating system to create an electronic survey with specific questions for the eleven educational programs of the UAEM Zumpango University Center, which will speed up the obtaining of academic competency indexes that the graduates require to obtain and / or preserve the job.

\section{Specific objectives}

1. Verify that the requirements of each of the educational programs of the UAEM Zumpango University Center are within the replies of the ALFA TUNING questionnaire.

2. Systematize the questionnaire. Using the PHP language (php.net) and the use of MySQL (mysql.com) creates the report generator system.

3. Create the survey in LimeSurvey. 
4. Program modules in javascript using jQuery (jquery.com) to improve the appearance of the interface and presentation of questionnaires.

5. Develop the web application for reporting.

6. Capture information of the questionnaires via the web and configure the dynamic behavior of the questions, according to the presentation of reports requested on the web.

7. Prove that the questionnaires retain their validity and reliability with what was originally designed (Tamayo, 2002).

8. Prove that this process of independent data capture and storage is interrelated with the academic competence indexes required by the accreditation bodies.

\section{Scientific Methodology}

Phase 0 . Validity of content of questions. Consultants of coordinators for each educational program of the Centro Universitario UAEM Zumpango, in order to know the specific needs of each of them in relation to the information contained in the ALFA TUNING Questionnaire.

Phase 1. Pilot test of the system questionnaire. Non-experimental design with statistical verification applied to a random sample of five graduates from eleven careers at the Centro Universitario UAEM Zumpango and one employer by educational area. Total of the sample to verify the veracity and reliability of the systematization of the questionnaires for graduates and employers consists of 55 graduates and 5 employers (Tamayo, 2002). Because ALFA TUNING questionnaire, already has validity and standardization done with university students and Latin American employers.

Phase 2. Application of the product. Non-experimental design, with cross-section and descriptive statistics. Applied to the population of 232 graduates of the University Center UAEM Zumpango, from the generations 2012 to the 2015, distributed in eleven groups (belonging to 2 Engineering careers and 9 Bachelor's degrees) to obtain the information of the questionnaire for graduates (Tintaya, 1999). 
Phase 3. Application of the product. Non-experimental design, with cross-section and descriptive statistics. Applied to the population of 55 employers in the Zumpango area to obtain the information of the questionnaire for employers (Tintaya, 1999).

\section{Variables}

Independent Variable: Systematized Questionnaire type Electronic Survey LimeSurvey.

Dependent Variables: 1) Time, measured in hours, two hours per week stipulated by the academic coordinators to carry out the activity of follow-up report of graduates; 2) Cost, measured by salary tab where the average monthly salary of the academic coordinator is $\$$ 10, 667.63 (UAEM, 2016. Tabulador Salarial).

\section{Hypothesis}

$\mathrm{H}_{1}$. If the ALFA TUNING Electronic Survey is applied through the LimeSurvey Operating System for graduates and employers, it will be $\geq 2$ hours a week, the number of hours generally assigned by the academic coordinators to obtain information required by the accreditation bodies.

$\mathrm{H}_{0}$. If the ALFA TUNING Electronic Survey is applied through the LimeSurvey Operating System for graduates and employers, it will NOT be $\geq 2$ hours a week, the number of hours generally assigned by the academic coordinators to obtain information required by the accreditation bodies.

$\mathrm{H}_{1}$. If the ALFA TUNING Electronic Survey is applied through the LimeSurvey Operating System for graduates and employers, it will be $\geq \$ 10,667.63$ the average monetary cost of career academic coordinators to obtain information required by accrediting agencies.

$\mathrm{H}_{0}$. If the ALFA TUNING Electronic Survey is applied through the LimeSurvey Operating System for graduates and employers it will NOT be $\geq \$ 10,667.63$ the average monetary cost of career academic coordinators to obtain information required by accrediting bodies. 


\section{Material}

1. Technical sheet of the ALFA TUNING Questionnaire.

The questionnaire consists of twenty-seven reagents. They measure academic competences divided into: a) Instrumental competences that evaluate competences of cognitive and methodological skills, such as technological and linguistic skills (ten reactants); B) Interpersonal competences that evaluate critical and self-critical skills, such as social and ethical skills (seven reactants); And c) Systemic or integrative competences (ten reagents).

Each reagent has a scale of 1 to 4 , where 1 means none and 4 means high, to differentiate the importance of the competence to obtain or keep the work in the opinion of the graduates and the level of accomplishment or achievement in the exercise of the Competition that employers require in employment (Beneitone, Esquetini, González, Maletá, Siufi, and Wagenaar, 2007, González and Suarez, 2016).

The concurrent validity of replies in the graduates' questionnaire is $89.92 \%$, while the questionnaire for employers is $81.66 \%$, in the population of the State of Mexico (González and Suarez, 2016).

\section{Systematization of a survey questionnaire.}

The system for electronic surveys of followers of graduates and employers developed is an application with web design adaptable (Responsive web design). The application allows to capture the questions that will be asked to the graduates and employers and to introduce the logic that guides the presentation of each question to the respondents. It also provides the facilities to configure the general parameters of the survey (start time, registration form, visualization, etc.) and to generate graphical and tabular reports.

There are three users in the system, called: Administrator, User (graduates and employers) and Academic Coordinator. The Administrator user is responsible for capturing the survey questions and for generating and entering the necessary logic. The type Usuariose registers and answers the survey. The Academic Coordinator type can 
access the statistical reports that are generated with the answers of the graduates and employers.

As can be seen in Figure 1, each type of user interacts with the application through a web browser. The browsers with which the application has been tested are Safari, Microsoft Edge, Chrome, Opera and Firefox.

Figure 1. User types and their tasks in the system of surveys for follow-up graduates and employers.

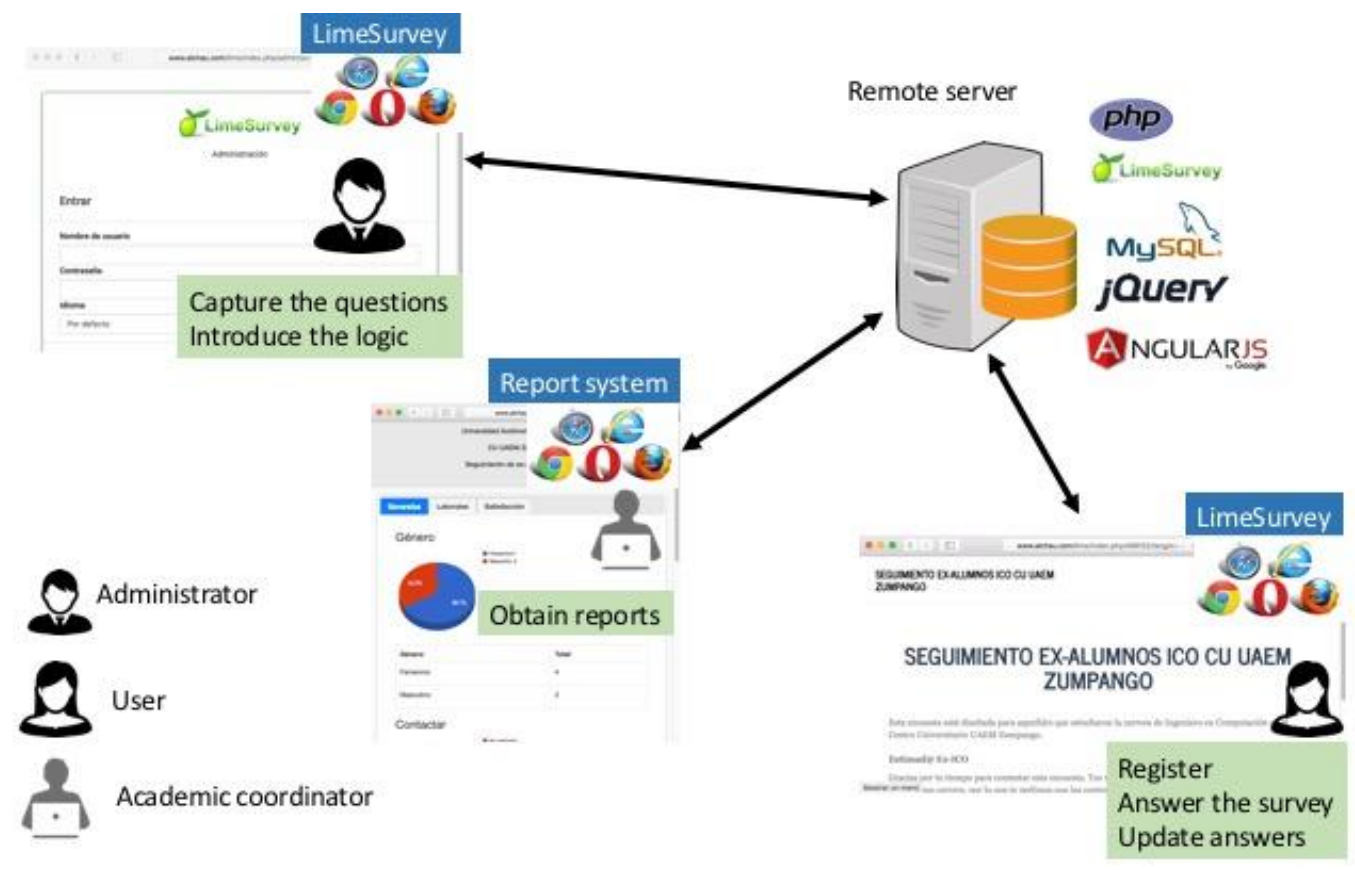

There are several technologies involved in the development of the system. On the Remote Server side, the PHP language was used to implement the report generator system driver, and MySQL to manage its model. The Javascript Frameworks (jQuery and AngularJS) files, as well as those in the Google Charts library, are stored on the Remote Server and uploaded to the Client when the Client accesses the application.

\section{Creating surveys with LimeSurvey.}

For the creation and application of the surveys, it was decided to use LimeSurvey, one of the most widely used open source applications for this purpose. 
LimeSurvey has all the necessary features to generate surveys with questions of various types. These characteristics include the following: a) Ability to create surveys in more than 80 languages, b) It has a wide repertoire of types of questions, 28 in total, c) It has the ability to create conditions that depend on previous answers to hide or show D) Provides the possibility of exporting results to several different formats, and e) Generates statistical reports of responses.

Although LimeSurvey is able to generate statistical reports and present tables or graphs, it has the disadvantage that it is necessary to make some filter configurations in each query.

In order to facilitate the consultation of reports related to the applied surveys, a web application was developed that allows the visualization of reports without having to make any configuration on the part of the user.

2. Web application for reporting.

The application driver was implemented in PHP language. The main tasks of the controller are: manage the session of the Academic Coordinator user and establish communication with the application model. Communication with the model includes queries to generate the statistical reports presented to the Academic Coordinator.

The application view is generated using mainly HTML, JQuery and Google Charts. With HTML the page is generated, whereas jQuery improves the appearance of it. In addition, jQuery AJAX (Asynchronous JavaScript And XML) is used to perform invocations to controller functions. Google Charts was used to represent the data graphically. Other technologies involved are Bootstrap to make the view adaptable to different screen sizes, and AngularJS to synchronize data updates between the view and the model.

The Academic Coordinator user must use a web browser to view the statistics. Figure 2 shows the technologies involved to generate the view and the driver of the developed application. 
Figure 2. Technologies used in the system reports for follow-up of graduates.

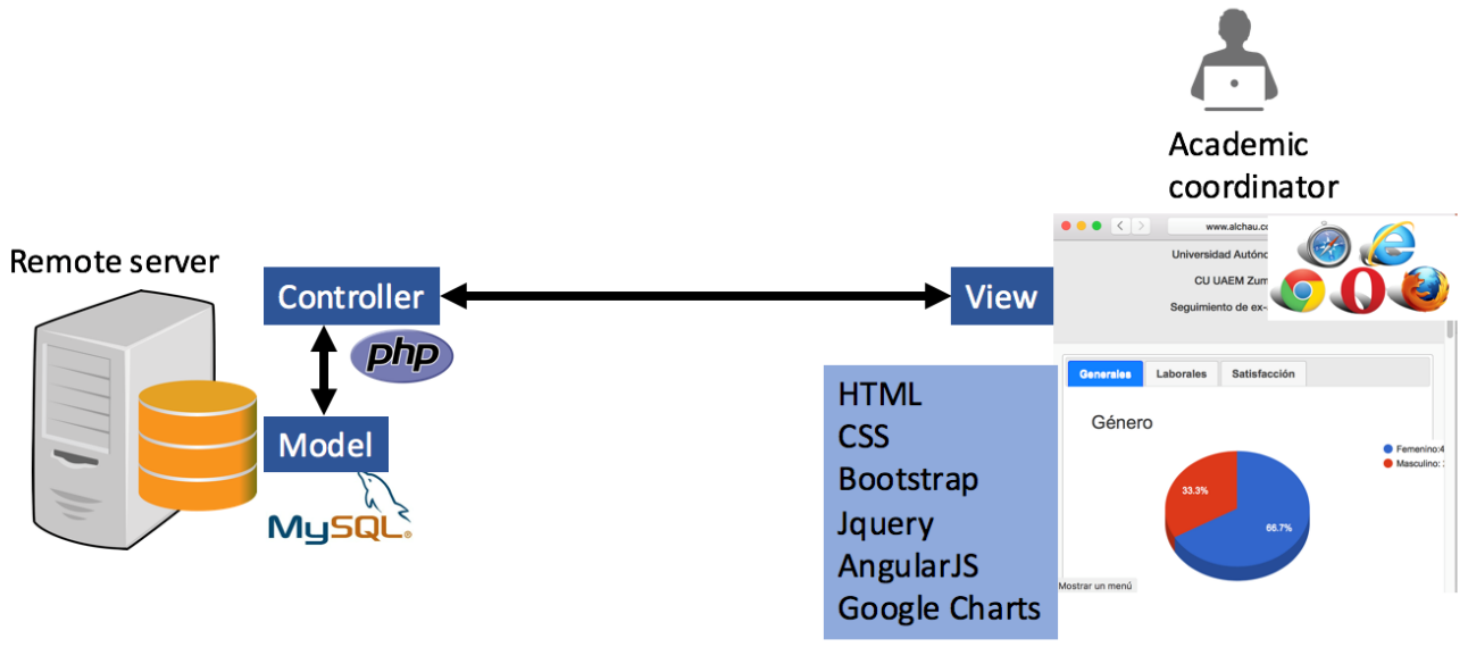

The answers of the answered surveys are stored in a single table by the LimeSurvey manager. In order to make queries to this table, and in this way generate reports, you must first know the name that LimeSurvey assigns you each column. PhpMyAdmin was used to get the names of the columns.

\section{Complementary activities in the use of the LimeSurvey survey}

Create manuals for users: academic coordinators, graduates and employers, to integrate them into the website.

Train academic coordinators to obtain data, either for the analysis of performance per career in terms of its academic ability and competitiveness and / or the data required by the certifying organizations.

\section{Results}

Table 2 shows the main characteristics of the sample through a descriptive analysis. Obtaining that the majority of the evaluated graduates belong Law Degree, for small private organizations and of the sector of services. 
Table 2. Characteristics of the samples. Graduates $n=232$, Employees $n=55$.

\begin{tabular}{lcc|lcc}
\hline Carreras & $\mathrm{n}$ & $\%$ & Organización & $\mathrm{n}$ & $\%$ \\
\hline & & & Tipo & & \\
Lic. Administración & 25 & $11 \%$ & Pública & 20 & $36 \%$ \\
Lic. Ciencias Políticas y Sociales & 14 & $6 \%$ & Privada & 29 & $53 \%$ \\
Lic. Contaduría & 28 & $12 \%$ & Otros & 6 & $11 \%$ \\
& & & Tamaño & & \\
Lic. Derecho & 41 & $18 \%$ & Grande & 8 & $15 \%$ \\
Lic. Sociología & 15 & $6 \%$ & Mediana & 14 & $25 \%$ \\
Lic. Enfermería & 14 & $6 \%$ & Pequeña & 33 & $60 \%$ \\
& & & Sector de Producción & & \\
Ing. Agrónomo en Producción & 12 & $5 \%$ & Primario & 8 & $15 \%$ \\
Ing. Computación & 21 & $9 \%$ & Secundario & 14 & $25 \%$ \\
Lic. Psicología & 25 & $11 \%$ & Terciario & 29 & $53 \%$ \\
Lic. Diseño Industrial & 16 & $7 \%$ & Cuaternario & 3 & $5 \%$ \\
Lic. Turismo & 21 & $9 \%$ & Quinario & 1 & $2 \%$ \\
\hline
\end{tabular}

Fuente: Encuesta por sistema LimeSurvey, 2016.

Figure 3 shows a descriptive analysis of the characteristics of the sample comparing the indices of trainees, graduates and graduates over six years.

Figure 3. Characteristics of the sample.

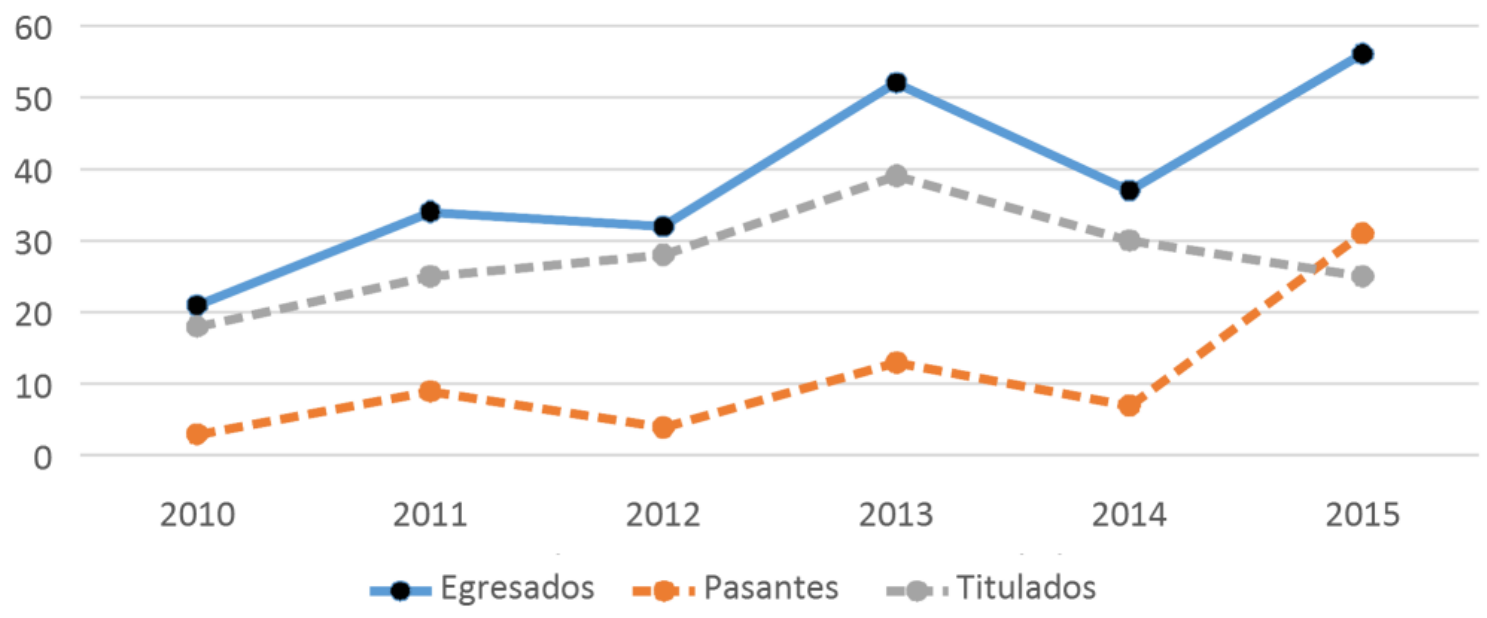

Source: Encuesta por sistema LimeSurvey, 2016. 
Table 3 shows a stacked column chart showing the parts of a total, which is the Global Titling Index. Noting the percentage of degree in terms of egress over six years of the 11 careers of the Centro Universitario UAEM Zumpango.

Table 3. Overall titration index per career.

\begin{tabular}{|c|c|c|c|c|c|c|}
\hline \multicolumn{7}{|c|}{$n=1,418$} \\
\hline \multirow[b]{2}{*}{ careras } & \multicolumn{5}{|c|}{ Años } & \multirow[b]{2}{*}{2015} \\
\hline & 2010 & 2011 & 2012 & 2013 & 2014 & \\
\hline IAP & 130.8 & 47.4 & 69.23 & 66.7 & 72.2 & 108.30 \\
\hline ICO & 41.2 & 84.6 & 177.78 & 40.7 & 61.9 & 151.94 \\
\hline LAM & 83.3 & 46.9 & 57.58 & 52.8 & 35.9 & 68.02 \\
\hline LCPAP & 90.6 & 100 & 42.31 & 60.6 & 50 & 82.50 \\
\hline LCN & 111.5 & 53.6 & 67.57 & 81.3 & 62.1 & 76.43 \\
\hline LDE & 102.1 & 80.6 & 55.56 & 60.0 & 63.9 & 106.50 \\
\hline LDI & 16.7 & 33.3 & 130.77 & 80.0 & 27.3 & 34.13 \\
\hline LEN & 87.9 & 71 & 79.31 & 76.7 & 36.2 & 47.17 \\
\hline LPS & 130.0 & 75 & 51.22 & 110.8 & 40.9 & 36.91 \\
\hline LSO & 23.1 & 37.5 & 68.42 & 114.3 & 14.3 & 12.51 \\
\hline LTU & 107.7 & 166.7 & 31.71 & 119.4 & 66.7 & 55.88 \\
\hline Total & 88.59 & 68.4 & 62.35 & 75.6 & 47.8 & 63.20 \\
\hline
\end{tabular}

Source: Encuesta por sistema LimeSurvey, 2016.

Table 4 shows the behavior of graduates with and without title and their behavior in the labor market by their percentage capacity to have employment in their area of study over six years. 
Table 4. Sample and percentage of employment in your area of study and in another area,

$$
n=232 \text {. }
$$

\begin{tabular}{c|ccc|ccc}
\hline $\begin{array}{c}\text { Año de } \\
\text { Egreso }\end{array}$ & $\begin{array}{c}\text { Egresados } \\
\text { sin Título }\end{array}$ & $\begin{array}{c}\text { Empleo } \\
\text { área de } \\
\text { estudio }\end{array}$ & $\begin{array}{c}\text { Empleo en } \\
\text { otra área de } \\
\text { estudio }\end{array}$ & $\begin{array}{c}\text { Egresados } \\
\text { con Título }\end{array}$ & $\begin{array}{c}\text { Empleo } \\
\text { área de } \\
\text { estudio }\end{array}$ & $\begin{array}{c}\text { Empleo en } \\
\text { otra área de } \\
\text { estudio }\end{array}$ \\
\hline 2010 & 3 & 0 & 3 & 18 & 16 & 2 \\
2011 & 9 & 4 & 5 & 25 & 21 & 3 \\
2012 & 4 & 2 & 2 & 28 & 21 & 7 \\
2013 & 13 & 5 & 7 & 39 & 29 & 10 \\
2014 & 7 & 3 & 4 & 30 & 24 & 6 \\
2015 & 31 & 11 & 20 & 25 & 20 & 5 \\
Total & 67 & $25(37 \%)$ & $41(61 \%)$ & 165 & $131(79 \%)$ & $34(21 \%)$ \\
\hline
\end{tabular}

Source: Encuesta por sistema LimeSurvey, 2016.

Table 5 contains different measures according to time. Where you can see the time stipulated by the academic coordinators to carry out the follow-up of graduates and until the time used in each one of the investigations by the academic coordinators in the same activity.

Table 5. Comparison of Time Investigations.

\begin{tabular}{|c|c|c|c|c|c|c|c|c|c|c|}
\hline Investigación & Sistemas & 1 & 2 & 3 & 4 & 5 & 6 & 7 & 8 & 9 \\
\hline pilotaje RIDE & SISE & 556 & 24 & 18 & 36 & 0.065 & 1.50 & 1.565 & 2.61 & 3.01 \\
\hline $\begin{array}{l}\text { alumni } \\
\text { universidad } \\
\text { RICSH }\end{array}$ & alumni & 1125 & 17 & 12 & 24 & 0.021 & 1.41 & 1.433 & 2.39 & 2.39 \\
\hline $\begin{array}{l}\text { movi } \\
\text { universidad } \\
\text { RIDE }\end{array}$ & movilidad & 372 & 54 & 14 & 28 & 0.075 & 0.52 & 0.594 & 0.99 & 1.39 \\
\hline $\begin{array}{l}\text { alumni } \\
\text { zumpango REPI }\end{array}$ & alumni & 172 & 37 & 15 & 30 & 0.174 & 0.81 & 0.985 & 1.64 & 2.04 \\
\hline $\begin{array}{l}\text { movi argentina } \\
\text { REPAM }\end{array}$ & UNL-Pam & 79 & 27 & 12 & 24 & 0.304 & 0.89 & 1.193 & 1.99 & 2.39 \\
\hline LimeSurvey & LimeSurvey & 232 & 55 & 3 & 6 & 0.026 & 0.11 & 0.135 & 0.22 & 0.22 \\
\hline
\end{tabular}


obtain data of graduates; 6 Amount of hours used to obtain data from employers; 7 Total time used to obtain data follow-up of graduates; 8 Total time converted to hours; 9 Conversion in hours and minutes. Sources: Studies conducted by researchers with different systems and Survey by system LimeSurvey, 2016.

Table 6 contains different measures according to Cost. Where you can see the cost per hour of the academic coordinators (salary tabulator, 2016; UAEM) to track the graduates and the cost used in each of the investigations by the academic coordinators in the same activity.

Table 6. Comparison of Investigations by Cost.

\begin{tabular}{|c|c|c|c|c|c|c|c|c|c|c|}
\hline Investigación & Sistemas & 1 & 2 & 3 & 4 & 5 & 6 & 7 & 8 & 9 \\
\hline pilotaje RIDE & SISE & 556 & 24 & 18 & 36 & 67 & 2412 & 4.338 & 100.500 & 104.838 \\
\hline $\begin{array}{l}\text { alumni } \\
\text { universidad } \\
\text { RICSH }\end{array}$ & alumni & 1125 & 17 & 12 & 24 & 67 & 1608 & 1.429 & 94.588 & 96.018 \\
\hline $\begin{array}{l}\text { movi } \\
\text { universidad } \\
\text { RIDE }\end{array}$ & movilidad & 372 & 54 & 14 & 28 & 67 & 1876 & 5.043 & 34.741 & 39.784 \\
\hline $\begin{array}{l}\text { alumni } \\
\text { zumpango REPI }\end{array}$ & alumni & 172 & 37 & 15 & 30 & 67 & 2010 & 11.686 & 54.324 & 66.010 \\
\hline $\begin{array}{l}\text { movi argentina } \\
\text { REPAM }\end{array}$ & UNL-Pam & 79 & 27 & 12 & 24 & 67 & 1608 & 20.354 & 59.556 & 79.910 \\
\hline LimeSurvey & LimeSurvey & 232 & 55 & 3 & 6 & 67 & 402 & 1.733 & 7.309 & 9.042 \\
\hline
\end{tabular}

1 Number of graduates evaluated; 2 Number of companies evaluated; 3 Weeks worked to obtain data followup of graduates; 4 Two hours of work stipulated by the academic coordinator; 5 Cost per hour of academic coordinator (Salary Tabulator, 2016; UAEM); 6 Cost to obtain graduates data; 7 Cost to obtain data from employers; 8 Total cost used to obtain data follow-up of graduates; 9 Total cost to obtain the entire study of follow-up graduates. Sources: Studies conducted by researchers with different systems and Survey by system LimeSurvey, 2016. 


\section{Discussion}

The implementation of the LimeSurvey system to the ALFA TUMING Questionnaire sought the ALFA TUNING Electronic Survey, which is an innovative, specific and necessary product, applied in an agile, intuitive, truthful and reliable way for users. Which measures the academic competencies of graduates to achieve and retain their employment in the labor market.

Within this research the ALFA TUNING Electronic Survey was used with graduates of the UAEM Zumpango University Center and employers in the Zumpango Region to know the impact of the LimeSurvey system on the time and cost of obtaining data required by the academic coordinators To obtain the information requested by the accreditation bodies.

The information presented here in the Results section is an example of some of the indexes that can be obtained only by filtering the data. Indices frequently requested in the accreditations for being longitudinal studies.

Recalling that our dependent variables are 1) Time, measured in hours, two hours per week stipulated by the academic coordinators to perform the activity of the follow-up report of graduates and 2) Cost, measured by salary tabulation, corresponding to 66.67 pesos per hour.

The first hypothesis is a function of time to obtain results. Affirming that: if the ALFA TUNING Electronic Survey is applied through the LimeSurvey system for graduates and employers the time will be $\geq 2$ hrs. Per week to obtain information required by accrediting agencies.

In the results that appear in Table 3 we observe that there are two systems that have times> 2 hrs. In which are found the systems used by the International University Mobility Program (PMUI) platforms and the LimeSurvey system, although the difference in time is relevant because the time used in the LimeSurvey system is six times smaller than the system used in The PMUI platform.

Regarding the second hypothesis that is formulated according to the cost, which says: if the ALFA TUNING Electronic Survey is applied through the LimeSurvey Operating System for 
graduates and employers will be $\geq \$ 10,667.63$, average monetary cost of career academic coordinators to obtain Information required by the accreditation bodies. The results expressed in Table 5 show that the ALFA TUNING Electronic Survey through the LimeSurvey operating system obtains a lower cost, which is $\$ 9,042$.

\section{Conclusion}

The LimeSurvey Operating System gives graduates' follow-up programs the evaluation and certification of the quality of institutions of higher education, such as the terminal efficiency index, the global titling index, the labor market entry index Educational area and labor aging index among others. These indexes determine the ultimate goal to be fully qualified for students to enter and integrate effectively into the labor market.

Therefore, having an electronic tool that facilitates obtaining these indexes in an agile, intuitive, truthful and reliable way for the Administrator and the Users, will give an overview of the general and detailed behavior of the institution in question to define strategies for educational improvement. 


\section{Bibliography}

Cano, García M.E. (2008) "La evaluación por competencias en la educación superior". Profesorado. Revista de currículum y formación del profesorado, 3, (12), 1-16. $\begin{array}{llllll}\text { Recuperado el } & 9 & \text { de } & \text { agosto } & 2016 & \text { de: }\end{array}$ http://www.ugr.es/local/recfpro/rev123COL1.pdf

Del Castillo Vázquez, J.C. (2010) El Marco General para los Procesos de Acreditación de Programas Académicos de Nivel Superior. Consejo para la Acreditación de la Educación Superior A.C. (COPAES). Recuperado el 9 de diciembre de 2016 de http://sep.gob.mx/work/models/sep1/Resource/920/1/images/elmarcogralprogacad.p df

Donolo, D., Chiecher, A. y Rinaudo, M. (2004). Estudiantes, estrategias y contextos de aprendizaje presencial y virtual. Recuperado el 25 noviembre de 2016 de: http://www.virtual.unlar.edu.ar/jornadas-conferencias-seminarios/jornada-interprovead/2003_3ra/ponencias-y-trans/est-cog-y-estr-apr.pdf

Esteve, J. M. (2009). La educación en la sociedad del conocimiento. Una tercera revolución educativa. Universidad de Málaga. España: Grupo de Trabajo sobre profesionalización docente de PREAL. Recuperado el 9 de octubre de 2016 de: www.oei.es/reformaseducativas/educacion_sociedad_conocimiento_t...

Beneitone, P., Esquetini, C., González, J., Maletá, M. M., Siufi, G., y Wagenaar, R. (2007).Reflexiones y perspectivas de la Educación Superior en América Latina. Informe Final - Proyecto TUNING - América Latina 2004-2007 (also published in English and Portuguese). Bilbao / Groningen: Universidad de Deusto / Universidad de Groningen. Recuperado el 9 de octubre de 2016 de: tuning.unideusto.org/tuningal/index.php?option=com_docman\&task=down.

Fernández, R., Fernández F., Álvarez S. y Martínez C. (2007) Éxito académico y satisfacción de los estudiantes con la enseñanza universitaria, Revista Electrónica de Investigación y Evaluación Educativa. Relieve, 13, (2), 203-214, Recuperado el 15 
de septiembre de 2016 de: http://www.uv.es/RELIEVE/v13n2/RELIEVEv13n2_4.htm.

González Jaimes, Elvira y Suárez Munguía, Eliseo (2016) “Adaptación, validación y estandarización de cuestionarios para egresados y empleadores, Estado de México”. Revista Iberoamericana para la Investigación y Desarrollo Educativo. Recuperado el 15 de noviembre de 2016 de: (http://www.ride.org.mx/index.php/RIDE/article/view/222/1003)

González Julia y Wagenaar Robert (2006) TUNING Educational Structures in Europe II. Universidad de Deusto, Bilbao Recuperado el 9 de enero de 2017 de: http://www.unideusto.org/TUNINGeu/images/stories/Publications/TUNING_2_CAS T_PR2_pdf.pdf

Hogan, T. (2004). Pruebas psicológicas. Una introducción práctica. México: Manual Moderno. Recuperado el 18 noviembre de 2016 de: http://web.usach.cl/psicologia/congreso/programa_cientifico.pdf

Román, J. M. y Gallego, S. (1994). Escalas de estrategias de aprendizaje. (ACRA). México: Manual Moderno.

Tintaya, P. (1999). Diseños de investigación; La Paz: CISPE

Tamayo, T. (2002): El proceso de la investigación científica: México, Limusa.

UAEM, (2008) Legislación Universitaria. Reglamento de Estudios Profesionales, articulo 04, pág. 193. Universidad Autónoma del Estado de México.

UAEM, (2016) Manual de Descripción de Puestos y Tabulador Salarial. Tabulador Salarial, 03 pág. Universidad Autónoma del Estado de México. http://transparencia.uaemex.mx/usuario/infPub.php?nomDir=03.catPueTabSal\&cveP arent $=5$ 
Valenti Nigrini, Giovana y Varela Petito Gonzalo (2004) Diagnóstico sobre el estado actual de los estudios de egresados, ANUIES (México) Recuperado el 9 de septiembre 2016 de: www.anuies.mx/e_proyectos/pdf/Estudios_de_Egresados.pdf

\section{Páginas web de apoyo:}

MySQL (https://www.mysql.com/ ),

PHP y LimeSurvey (https://www.limesurvey.org/)

jQuery (https://jquery.com/) 